\title{
THE GREAT GRAY OWL
}

\section{E. T. JONES, 10106 - 138 St., Edmonton, Alta.}

Certainly one of the rarest birds now found in Canada is the seldom seen Great Gray Owl. For two successive years my associate, Mr. Al Oeming, who incidently is one of the few active falconers in Canada, and myself have searched in vain for the nest of this beautiful large Owl. Our travels of over ten thousand miles have taken us through hundreds of miles of virgin timber on horse-back and often by foot. To date not one of these birds has been seen alive! On several occasions we have arrived a few days or a few weeks too late, only to find the carcass of one of these birds outside the trapper's cabin. Numerous reports and leads by farmers, trappers and lumbermen, invariably end in us viewing the nest of the Horned Owl, which admittedly, can easily be mistaken for our quarry by the unfamiliar.

To aid in our search a very complete booklet has recently been prepared and circulated throughout northern Alberta. Almost 5,000 have been distributed to trappers, rangers, and any others that might be able to supply information. The return to date has been interesting, and it is my hope that anyone reading this article who has in the past or in recent years encountered the Great Gray Owl, in any part of Canada, will write me at the above address. It will be my pleasure to forward a booklet to anyone wishing same. Any information as to the type of country where the species has been encountered, nests seen, the birds observed, will all be helpful in our project.

The purpose of this search, speaking for myself, is to record on color film, as much of the home life of this Owl as is possible to get. For my associate, it means the writing of a life history of a bird which appears to be close on the footsteps of the beautiful Whooping Crane. There is no doubt that the predations of man will eventually force this species into extinction. We look with anticipation to the readers of the Blue Jay, as a possible source of information that may eventually

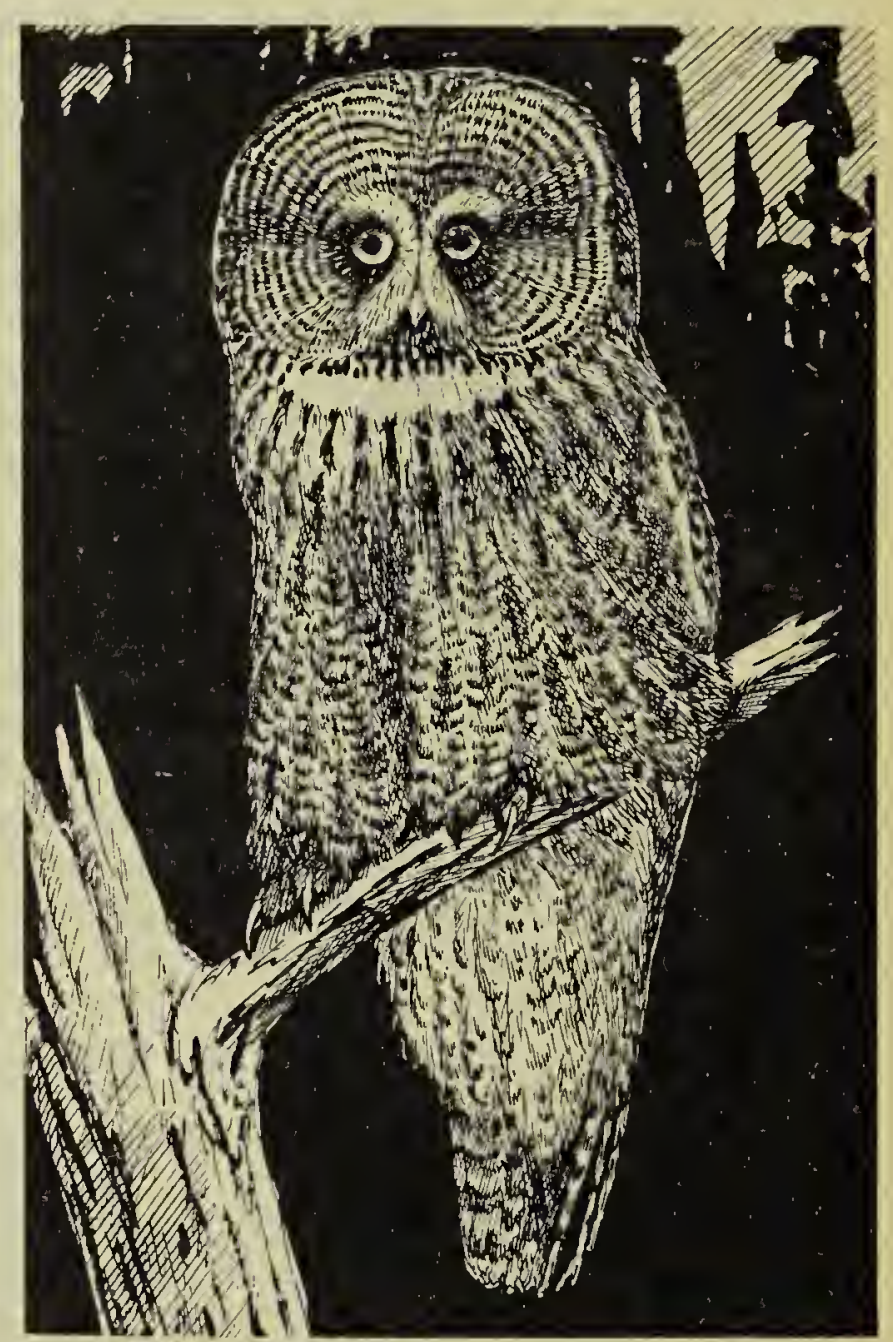

Have You Seen This Bird?

lead to the finding of the nest of "Scotiaptex Nebulosa," the Great Gray Owl.

\section{The Speed of Flight}

\section{A. J. HUDSON, Mortlach, Sask.}

Observing a Short-eared Owl leisurely floating along, one hardly realizes the speed at which it travels in its effortless flight.

Last Sunday (Dec. 27) on my way out on a country road south of Mortlack, I flushed one such bird. He headed straight down the road above the grass to the left of me, occasionally beating his wings and at other times just gliding. I was travelling at 35 , yet it was drawing away from me. At 40, I began to creep up a little. The bird angled across the road, but stayed ahead of the car, and on the right-hand side of the road, even at a slight angle to my line of travel, still stayed ahead. Only when he veered off at a larger angle, did I pass him. 